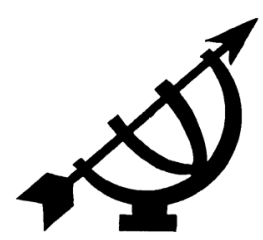

\title{
When western leadership models become a mixed blessing
}

J. Reimer 1

Professor Extraordinarius

Department of Church History, Christian Spirituality \& Missiology University of South Africa

PRETORIA

and

Lecturer at the Theologisches Seminar Ewersbach

Germany

E-mail: johannes.reimer@gbfe.org

Abstract

When western leadership models become a mixed blessing

Russia plunged into a deep leadership crisis after the collapse of the Soviet Union. The attempt to implement western leadership models only deepened the crisis. With the take over of power by Vladimir Putin a new leadership theory evolved, which looked critically at western models. Totalitarianism, contextuality, cultural sensibility and pragmatism are issues being investigated with respect to leadership. This article includes these themes whilst reflecting on the critical dialogue between the American leadership expert Stephen R. Covey and his Russian critic Vladimir Tarassenko.

\section{Opsomming}

\section{Wanneer westerse leierskapsmodelle 'n gemengde seën is}

Rusland is ná die ineenstorting van die Sowjetunie in 'n ernstige leierskapskrisis gedompel. Die poging om westerse leierskapsmodelle te implementeer het die krisis net verdiep. Met die oorname van gesag deur Vladimir Putin, het 'n nuwe leierskapstyl die lig gesien wat krities na westerse modelle gekyk

1 Dr Johannes Reimer is Professor Extraordinarius in the Department of Church History, Christian Spirituality and Missiology at the University of South Africa. He is also the president of the GBFE (Gesellschaft für Bildung und Forschung in Europa). This article is part of the Christian Leadership in Context project. 
het. Totalitarisme, kontekstualiteit, kulturele sensitiwiteit en pragmatisme word in hierdie artikel ondersoek terwyl besin word oor die kritiese dialoog tussen die Amerikaanse leierskap deskundige Stephen R. Covey en sy Russiese kritikus Vladimir Tarassenko.

\section{The post-Soviet society - a society in ideological vacuum}

The collapse of the Soviet system led in several ways to a social crisis - this was caused by the ideological and spiritual vacuum that had emerged in Russia. Such a crisis is known to also result in a leadership crisis. The old leaders are irritated, their leadership systems are no longer effective and new products must first be found and developed for a new context.

The democratic emergence under Gorbachev's perestroika2 banner was therefore also a departure for the Russian youth. Boris Nemcov (2007:5-6), one of the youngest ministers in the more recent Russian government, remembers:

At the end of the 1980s, and the beginning of the 1990s, we the young democrats were on our own. We could rely on nobody, we moved according to our intuition. For understandable reasons, there were no elders beside us, who were able to advise us to avoid making certain mistakes. We achieved a great deal, but we also made many mistakes.

Anyone who wants to understand these mistakes should refer to the time of the "great economic depression" as Chavance (1994:201) called it back then. Kagarlitsky (1995:75) painted quite a realistic picture when he wrote:

After the dismantling of the Soviet Union and the abolition of the controlled economy, the reformers promised to turn a new page in Russia's history. Everywhere changes were introduced, but these did not lead to renewal. Millions of people asked themselves: who are we, why are we being treated in this manner, and when will all this end? Some regarded the things that happened to them as a bad dream. Others had the impression,

2 The term perestroika can be described as reconstruction or transformation. The term refers to the social reconstruction programme of the former secretarygeneral of the communist party of the Soviet Union, Michael Gorbachev. The programme was triggered by the publication of Gorbachev's book with the German title Perestroika (Gorbatschow, 1987). 
that they had gone mad or at least felt themselves under extreme psychic strain. And this did not only happen to a group of people, but the entire state felt this way.

It was a time of incredible destruction; the country's economy was shattered. Production fell to less than a third of the level of the old Soviet Union, inflation galloped ahead and devalued the very scarce available money. Thousands of people lost their jobs. Within a few years a large portion of the Russian population was plunged below the poverty line. The enthusiasm with which the population had celebrated the end of the regime of the Soviet Union gave way to incredible disappointment. Was the renewal of Russian society which began with perestroika, only a further illusion, an utopia, "a road to nowhere", as Boettke (1993:12 ff.) once called it?

Nemcov admits that he made mistakes whilst others, who caused these mistakes, kept silent. After all, the young Russian government team was led by western economic strategists. In the end it was the western economists who prescribed the shock therapy which they claimed would lead directly to a "capitalist paradise". The naive belief of the western strategists, that the only appropriate way for a democratic development of Russia was the introduction of a free market, transpired to be a nasty surprise. Instead of real change a complete disaster followed. In the words of Steele (1994:291 ff.), it was a "big shock with little therapy"; the "capitalist modernisation collapsed" (Kagarlitsky, 1995:156).

At that time cautionary voices already existed in the West who regarded the disaster as homemade and who demanded alternatives. Chavance (1994:209), for example, wrote:

It is possible to fairly quickly dismantle an old economic system, but to create and stabilise a new one - that will take a lot of time. A realistic strategy for transformation should take into consideration that systemic changes include an evolutionary process and require gradual learning by people as well as of organisations and society collectively.

He therefore suggested that the approach that ought to be followed was that of a mixed post-Soviet economy (Chavance, 1994:210). The critics of depletion-capitalism proposed a third way. ${ }^{3}$

3 On this subject see the extremely interesting documentation of the Internationalen Symposium on the topic in Saslavskaya and Aratunyan (1994). 
Since then much time has passed. In Russia new political powers asserted themselves, gradually broke with the capitalist free market system and sought a distinctly Russian way. The first results are encouraging. Whatever the West thinks of Putin and his team - one thing is certain, today Russia is economically far better off than during the first post-Soviet phase. What has happened? What did Putin and his team do right, if what they did was indeed correct? Do determining factors exist which characterise this new leadership style in Russia? How can western leadership concepts or visions be compared to this new leadership theory?

It is hardly feasible within the parameters of a single article to answer the posed questions in any depth. It seems to be useful, however, to use the example of an academic discourse on the subject of leadership between representatives of the West and the present Russia to explain what constitutes the "third Russian leadership path".

\section{The re-awakened leadership awareness}

Since Putin's second tenure a change of awareness is noticeable in Russia; Russia and her intellectual elite have dared to lead again. Nemcov (2007:13) is correct when he writes: "When society asks for a new type of leader, a new phase of the development of a country is indicated." And he adds: "This characterises the present Russia: the nostalgia for the empire and pride about oneself, because everywhere in the country there are signs of prosperity."

A good example of the newly-awakened consciousness of the leadership debate is illustrated by the Russian leadership specialist $\mathrm{Dr}$ Vladislav Tarassenko's4 (2008) engagement with the theories of the American best-selling author and leadership expert Stephen R. Covey. 5 Covey's book, The seven habits of highly successful people (1989; in Russian: Kovi, 2008)6 sold more than fifteen million copies

$4 \quad$ Vladislav Tarassenko teaches strategic leadership at the Institute for Business and Leadership at the Economic Academy of the Russian Government in Moscow. He is also a scientific associate at the Institute for Philosophy at the Russian Academy of Sciences. He also leads the business consultancy "Tarassenko and Partner" - one of the most prominent business consulting firms in Russia, situated in Moscow (Tarassenko, 2008:183).

5 For Covey's offer for self-promotion in leadership training, cf. http://www. franklincovey.com/tc/

6 Published in German under the title: Die sieben Wege zur Effektivität: ein Conzept zur Meisterung ihres beruflichen und privaten Lebens (München, 2000). 
worldwide. His important book, The 8th habit: from effectiveness to greatness, on effective organisational leadership was published in 2004 (Covey, 2006).

Tarassenko deals with both books and expressly sounds a warning about these "American products". His line of criticism is brilliantly drawn and reveals how effectively the new Russian elite has left the old leadership ideals behind and how sensitively they react to the most gently stated, seemingly authoritarian system. Tarassenko (2008:7) appeals to the Russian public that no one should be intellectually asleep ever again, because "the sleep of the intellect gives birth to the monster". Tarassenko responds to the so-called seven habits of effective leaders with his eleven warnings, each corresponding to Covey's claims. He calls them "poor advices". We investigate these warnings and will attempt to bring to light the postSoviet characteristics of the arguments. I am guided hereby by three fundamental decisions:

- Covey is presenting his basic habits as universal principles based in religious convictions. He is a Mormon by confession. Tarassenko professes to be an Orthodox believer. I will investigate the theological validity of their arguments.

- I am a missiologist by profession, committed to a holistic mission that is deeply rooted in the mission Dei.7 I am discussing leadership against the background of my mission-cultural interest. The key question will be, does the suggested leadership style really transform society for the better or not?

- I grew up in the former USSR. The question of societal and economic transformation in Russia is in many ways a personal issue for me. In seeking to be as objective as possible, I recognise my emotional involvement and subjectivity in writing this article.

As a rule the Russian edition with my own retranslation aided by the German translation, is cited. Where the German edition differs from the Russian text regarding the content, this will be specifically mentioned in the text.

7 See in this regard my recent book, Die Welt umarmen: Theologie des Gesellschaftsrelevanten Gemeindebaus (Reimer, 2009). 


\section{Tarassenko's critique of Covey}

\subsection{The organisation as source of good fortune and misfortune}

In his book, The 8th habit: from effectiveness to greatness, Covey (2006) claims that the reason why many people live in fear and are discontented is because the organisation in which they work does not give them satisfactory information regarding their aims and objectives. This results in discontent among the employees, inversely affecting their cooperation within the organisation. He recommends that the correlation between personal contentment or happiness and cooperation within the organisation must be heeded (Kovi, 2007:17). Cooperation in the organisation should make the employees happy, which would make them thoroughly effective.

Tarassenko questions Covey's claim of the existence of a correlation between the personal happiness of the employees and the development of an organisation. He turns the assertion around by asking if it would be correct to assume that a decline in the effectiveness of the individual and the organisation can be expected if the organisation in which the employees work is not a source of happiness (Tarassenko, 2008:25-26). His reply is in the negative. Good fortune and inner happiness, according to Tarassenko (2008:26), are personal and subjective entities which cannot be organised. One can certainly wish that everyone could pursue an occupation that satisfies his/her inner needs, but to demand from an organisation that it be the fountain of happiness for its employees is wrong - it is, in fact, dangerous. Whoever expects the organisation to be the wellspring of their happiness will sooner or later forfeit taking responsibility for their own lives and happiness, and will find themselves in a position of dangerous dependency on the company for which they work. In the end, they will become less effective.

Tarassenko knows what he is speaking about. He grew up within a Soviet culture in which people argued similarly. The happiness of employees was directly linked to the success of the organisation in which they worked. The outcome was disastrous - the prescribed happiness in the Soviet paradise turned out to be a reality that corroded and subverted the personalities of human beings.

Covey's advice to tie the employees emotionally to the company is thus only partly sensible. There is no question that people who enjoy going to work, people who consciously give their talents and capabilities and competencies to the organisation, and who do it 
with an inner conviction, are welcome in any organisation. Tarassenko does not deny this. What concerns him about Covey's advice is the fact that he elevates the emotional bonds to the level of a principle, in which case too much is expected of the organisation as well as the individual. What particularly concerns Tarassenko is that in the last analysis Covey's view promotes totalitarianism. This does not constitute an option for Tarassenko (2008:30) who has himself only recently escaped from a totalitarian system.

\subsection{Only painting in black-white makes the contrast too easy}

The formula "create fear and save" penetrates Covey's books. He paints in black and white whereby it is always made clear that beyond his insight everything is rather black, but with the implementation of his revelation, everything turns to white.

Tarassenko (2008:35) questions the rationality of such an approach. He writes:

Fear plus rescue - those are effective instruments of manipulation. Experienced leader manipulators will always feed their employees with fear, to subsequently nobly 'save' their subordinates.

Such leadership achieves, according to Tarassenko, a twofold goal. Firstly, it reduces the responsibility of the employees for him-/herself - who are, after all, in any event, dependent on the salvaging help of his/her superiors. Secondly, it promotes the segmentation of the firm into clans. Not the effectiveness of the organisation, but the authority of the leader takes first place and, in this manner, the company transforms itself into a clan (Tarassenko, 2008:37). He critiques the view that in a well-administered company the leadership tries to achieve collective performance through the blind obedience of its employees towards the leadership.

Tarassenko's criticism is again clearly rooted in the experience of decades of the Soviet tradition of strong party leaders. Within Soviet style socialism democratic leadership was literally unknown The Soviet authorities have worked with the same formula that Covey presents as tool of divine revelation to the managers of this world. That something of this nature is not well received by the thinking post-Soviet people is more than understandable.

The black and white schema of leadership misses out on both the cultural diversity of a given culture and the democratic structure of leadership. In a country such as Russia with all its painful past of 
witnessing the crushing of any democratic beginnings through the use of exactly this type of thinking, there will be little acceptance of Covey's wisdom.

\subsection{Believe in universal principles and remember that the map is not the territory}

Covey believes that the individual as well as the organisation largely depend on the compliance with so-called common principles. Such principles are, according to Covey, eternal; they do not change, they are not subject to vacillation of time and circumstances - life ultimately depends on them (Kovi, 2008:124, 128). In a life that uses the universal principles as foundation, Covey sees aptitudes for an effective existence (Kovi, 2008:133). For Covey God is the creator of these universal principles.

Tarassenko questions this position in a very fundamental way. He justifiably points out that all universals experience their concrete shape within the framework of respective cultures. Universals clad in cultural guise, however, quickly lose their general validity. It is thus not possible, as Covey deems it necessary, to postulate supratemporal and crosscultural principles, which are essentially always and everywhere the same. If one does it anyway, one becomes a cultural exporter, who might impose something totally foreign onto any given culture. One can, however, expect such an undertaking to fail. The practice of blindly taking over culturally biased principles usually leads, according to Tarassenko (2008:44-45), to a series of undesirable side effects, which essentially minimise the success of the enterprise.

- The acknowledgement of universal and generally relevant principles leads to a dangerous simplification of the reality of the cultural context. He, who looks at the everyday world from a particular perspective, will only see what his chosen perspective will permit. Tarassenko illustrates this with the illustration of the map and the territory. As is generally known, the map is not as yet the territory. The map is only a representation of the territory and it is easily possible that the cartographer, whilst recording the facts of the territory, made mistakes. Not the map, but rather the territory must be the criterion for authenticity. Thus, whoever prospectively interprets the territory, runs the risk of misconstruing the actual reality.

- Acknowledgement of universal valid principles which are always and everywhere correct, leads to the lowering of the personal 
responsibility of employees. Decisions are no longer made on the basis of responsible thinking, but because the predefined matrix of principles demands such a decision.

- The acknowledgement of universally valid principles eventually leads to a halt in development. Why should one endeavour to make an effort for improvement if one has already applied eternally valid principles?

- The acknowledgement of universally valid principles leads to an exaggerated self-confidence and with that a danger of an exaggerated opinion of oneself. In times of crisis, such an inflated self-assuredness can become life threatening for the organisation.

Tarassenko's criticism is understandable, if one again considers his origins. The ideology of the so-called scientific Marxism-Leninism tried precisely that. Supposedly universally valid parameters of a social and economic organisation for the community were formulated within this approach. This system, being utopia, then turned its back on the world stage. Covey's proposals are religiously and ideologically differently motivated, yet their sheer universality permits one to suspect that the final outcome which these proposals cause in a culture that differs in so many respects from the American culture, will not be very far from the Soviet catastrophe that we have seen.

\subsection{Override personal motives and interests through universal principles}

Covey suggests the repressing of the varying interests and motives of human beings on the basis of higher principles. In this manner, according to Covey, an energy arises within the community which, in the end, essentially decides the success or failure of the enterprise.

Tarassenko accepts Covey's initial thought that personal motives and interests can be suppressed through the acceptance of higher principles. He, however, justifiably asks whether such an undertaking should be part of a firm, or whether it should be guaranteed from outside the enterprise. Tarassenko (2008:58) writes:

The acceptance of principles as unalterable truth must, in my view, inevitably lead to an inner conflict and consequently to a struggle which will absorb the strength of a human being. If something of this kind happens in an organisation then we risk, instead of successfully producing together, to be in a constant 
debate with those who seek to spread the seed of the 'true principles'.

With this criticism, Tarassenko appears to be remembering the loud ideological gatherings held during the communist era. Every hall, company driveway and almost every workbench was decorated with slogans from the eternally valid catalogue of the communist statute books. Yet this brought nothing to fruition. This dread of the ideologisation of the working life of an organisation from the perspective of a nation that is tired of ideologies is understandable.

\subsection{Open the eyes of the people and set them free}

Covey demands of the leadership of an organisation that they facilitate the maximum freedom for their employees. They should even through cooperation in the organisation achieve personal freedom.

Tarassenko questions this approach and reveals both the logical incompatibility between a behaviouristic and existentialist approach, as well as the potential danger of malpractice by the organisation as a sole source of meaning for the particular employee. "It is dangerous and hazardous to perceive the organisation as existential social entity. ... The full realisation of such paradigm leads to the emergence of a totalitarian organisation," writes the Russian critic (Tarassenko, 2008:61 ff.). Exactly therein do totalitarian organisations find their strength, by promising the employees the full satisfaction of their personal needs. Yet the individual does not experience freedom in such a structure. Structures that determine meaning themselves, in the end, achieve the exact opposite of what Covey promises in his work.

It is not very difficult to understand why Tarassenko rejects the organisation and its leadership as a meaning-giving entity. The party organisation of the communists had promised the people of the Soviet Union exactly that. And precisely what Tarassenko today cautions his readers about, actually happened. Not meaning, but meaninglessness, was the result! The question of how the individual worker might experience the maximum of freedom and creativity within an organisational setting stays unanswered. Tarassenko criticises Covey without offering a solution himself. He takes Covey's argument to an ideological extreme, which, as far as I see, is not intended by the author. 


\subsection{The personal values of the employees must submit to the vision and mission of the organisation}

Covey makes the point that every organisation should be aware of its own vision and mission. In doing so, he supports the idea that these should not, as was "usual in the past", be decided in a topdown manner, but rather developed in close cooperation with the employees (Covey, 2006:240). An organisation, in which all employees have understood and accepted its vision and mission, is potentially successful. The opposite applies - where an organisation does not show a clear vision and mission, substantial setbacks can be expected.

Tarassenko closely examines Covey's postulate and seeks to identify the exact mission of an organisation. In doing so, he emphasises the social component of each and every vision and mission statement. Whilst such a statement may seem meaningful for nonprofit organisations, he questions the meaning of such instruments for a purely economically orientated structure. He fears a too strong idealisation of the economic system which, in the last analysis, could prove to be counter-productive for the economy and damaging to the personality of the individual employee (Tarassenko, 2008:8788). An industry that really fulfils its mission, is the tobacco industry, but, asks Tarassenko rather provokingly, can profits be made at the cost of health? Can pure profit interests be packaged in vision and mission statements? And what are such phrases worth if they cannot really be hedged by the organisation? And lastly, what impact does the pressure of the maximisation of profit have on the employees if they have to subordinate their own values to the vision and mission of the organisation? Tarassenko makes no mention of this, but it becomes evident in his exposition to what degree he fears the ideologisation of the economy, as it was customary during the time of the communist command economy. And his fear finds appropriate support from those who have seen the effects of such ideologically driven economy.

\subsection{Proactive and goal-orientated employees are more important than the lifecycle of the organisation}

The ideal employee, according to Covey, should be proactive, which for him, constitutes one of the principles of effectiveness. When employees are consciously and creatively forward-thinking as well as independently conforming to a set goal, then success is guaranteed. 
Tarassenko finds such activism suspect and argues that it reveals a blatant mistake in one's logic or reasoning. The development of an organisation is not only dependent on the attainment of its set goals. Organisations are functional and process orientated structures. Their effectiveness essentially depends on how meaningfully the set aims and objectives are reconciled with the functions and processes of an organisation. A mere setting of aims and objectives can thus have a negative converse effect on the development of an organisation. Tarassenko (2008:98) writes:

For a leader the question arises as to who amongst his employees should rather fulfil a function in the business, figuratively meant, who should rather be an official and who should be a goal-orientated, proactive missionary.

In his monograph on the paradigm change in economical theory, he goes into more detail about this question and makes the answer to this question dependent on two factors, namely the psychological condition and unusual qualities of the employee as well as the prevailing lifecycle of the business (Tarassenko, 2006; 2008:99). According to Adises (quoted in Tarassenko, 2008:99-100) every organisation experiences a lifecycle consisting of at least ten phases: the formation of a company, childhood, the active phase, youth, prime, stability, aristocracy, early bureaucracy, bureaucracy and death. Other authors categorise the lifecycle differently. Tarassenko emphasises this view and makes it clear that it is not always advisable to stimulate employees to be proactive. Depending on the circumstances in which the company finds itself, reactive action may be essential. For the development of healthy organisations in Russia, Tarassenko advises against imprudent American "hurrah-activism".

\subsection{Competence is the application of proper/correct technologies}

Covey tries to make it clear in his books that the good habits which lead to the effectiveness of employees and thereby also to organisations, are learnable. Competence is acquired through the accumulation of appropriate habits and this occurs through the learning and the application of expert knowledge. The requirements are applicable guides and technologies. If one complies with this correct advice, an amateur can become an expert and a loser can become a winner (Covey, 2000:46-60). Against this backdrop, Covey promotes himself as a competent advisor whose recognised principles decide the success or failure of an organisation. 
Tarassenko questions this severely simplified philosophy of the acquisition of competence. He (Tarassenko, 2008:111) writes:

Habits do not form as a result of the learning of a technology, which was revealed to some famous guru, but in the process of an impartial and confidence-building exchange of opinions, knowledge and experience.

Such an exchange does not necessarily require the availability of an initiated guru, but rather an appropriate social network. Human beings learn most effectively in groups and not when they are subjected to a formidable authority (Tarassenko, 2008:109 ff.). The greater the dependence of the employee on the correct technology and the appropriate leader, the less performance can be expected in the end. In this context Tarassenko refers to the studies conducted in the West by, for example, the IBM Institute for Business Value.8 As Lessner and Stork (2006:119 ff.) proved, social networks play an extremely critical role in the drawing of competence guidelines. The presence or absence of an atmosphere of joint learning in an organisation therefore has much greater consequences for the effectiveness of an organisation than to stubbornly follow the correct advice.

\subsection{Ideal managers guarantee the maximum organisational effectiveness}

People who find their leader-voice, according to the principles as proposed by Covey, and let themselves be moulded accordingly, have the prospect to become ideal managers and thereby would be guarantors for the success of the company of which they are in charge. That is for Tarassenko (2008:119), the quintessence of Covey's book, The 8th habit: from effectiveness to greatness.

Tarassenko doubts whether the ideal manager, if ever there were such a person, would also be ideal for the organisation. Tarassenko, together with the American leadership expert Adises (2007:26), questions the mere feasibility of an ideal leader and rejects such a notion as utopia. People are so different, and the organisations and the contexts according to which they are managed are so diverse, that any idealisation of particular leadership categories proves to be utopian from the outset. Adises calls such a manager a "mythical being". Whoever postulates and tries to mould such a leader, works 
with illusions, and Covey, according to Tarassenko (2008:121), does exactly that.

The impossibility of the existence of the ideal manager brings another problem clearly to the fore. If one assumes that it is possible that such a manager exists, as does Covey, one faces the danger of appointing the wrong man or woman at the wrong time and for the wrong reasons. People who believe that they can control any situation because they epitomise the correct leadership principles, are potentially dangerous for an enterprise. In fact, Adises (2007:235) warns against bringing the graduates of the Harvard Business School into the firm, because they "were taught to be the president and not the employee who can work with others". Tarassenko agrees with Adises and cautions against Covey's much praised principles.

\subsection{Managers are effective when they require mutual profit}

Covey (2000:192 ff.) mentions as his fourth principle in his cardinal book on the subject of effectiveness and leader competence, that which a successful leader should comply with when thinking "profitprofit". He postulates that the success and effectiveness of a manager is directly dependent on whether he/she is willing to accept profit as a mutual profit proceeding event. It is necessary, in order for such a reciprocal process to be achieved, to work on a behavioural agreement, starting with oneself and subsequently with the prospective partners. Social relationships, according to Covey, are fashioned effectively when they are created within the framework of a contract paradigm.

Tarassenko (2008:127) questions this postulate and says:

At the point of departure at which the attitudes and decisions of people are seen from the perspective of gain, nothing can be claimed to be a universal principle. Such an attitude soon proves to be ineffective in the realm of interpersonal relationships as well as in the behaviour of organisations.

In other words, leaders and managers need, in principle, to question Covey's approach. Can human, social, cultural behaviour be reduced to the motive of profit? Is it possible to measure relationships by means of trade categories? Is the paradigm of the contract universally applicable? Is the attempt to commercialise relationships justified? The answer is a clear no! There certainly are cultures, and the American culture is an example, in which relationships operate 
in a contract orientated manner. However, cultures are not all the same. Tarassenko (2008:134) warns:

I maintain that in such organisations and companies, in which the collective perceptions and convictions are not characterised by contracts, Covey's recommendation to think, 'profit-profit' in one's mind's eye, will not create effectiveness.

On the contrary, in collective and shame oriented cultures it is less the contract, but rather the powers of culture themselves, which determine relationships. The insistence on the contract can in such cases develop illusionary and highly ineffective relationships, which could have fatal implications for the development of the organisation.

\subsection{Effective leadership is only possible through a firm leadership style}

Covey is adamant that the individual voices of the employees in an organisation should be harmonised with that of management (Kovi, 2007:312), if it wants to become effective. Covey holds the view that the harmonising of the interests and motives of the employees with that of management should de facto lead to a heterarchy, the abolition of the necessity to lead from above, which for Covey constitutes the only effective form of cooperation in postmodern society.

Tarassenko (2008:146) regards specifically this point as being utopian, even dangerous, in its post-Soviet context. For one thing, different cultures organise the social and economic existence differently. The actual abolition of such social and cultural realities constitutes a complicated and protracted process. Such a thing is truly not a mandate for an organisation, and certainly not for a commercial company. Covey's request reveals his rather flawed understanding of culture. His insistence on his concept of harmonisation de facto leads to the implementation of totalitarian organisations in collectivist cultures, which have at their command a considerable revolutionary and conflict ridden potential. In this way employees are deprived of their right to decision making and are not built up and inspired, but rather harmonised - the reverse of the rosy picture of Covey's world of splendour actually appears.

\section{Look ahead: post-Harvard, post-Western}

Tarassenko's criticism of one of the most prominent leadership experts of the United States of America is important and revealing. 
For one thing, it reveals the revival of the self-awareness of the Russian leadership elite. What contributed to this growth in self-awareness? The disastrous state of the ruined Russian economy which resulted from the poor advice given by western experts during the Yelzin era and the huge economic success of Putin's government. Western expertise was for a long time first and foremost American expertise. During Putin's government, the general validity of western advice was effectively called into question. Few of the western models that tried to transfer successful American paradigms of capitalist economic activity into the Russian context were successful. Against this background the search for a version of Russian democracy and market economy, a Russian leadership style, was sought. 9 In his book Tarassenko encapsulates his criticism of the weak points of the leadership theory which was developed in the United States of America. This leadership theory is marked by four crucial disadvantages:

- The American leadership theory is being perceived as imperialistically oriented. It works with apparently universal principles which were, however, formulated within the framework of American culture, and for that reason they cannot serve their universalising purposes.

- The American leadership theory is perceived as being culturally alien, because it elevates itself above all other cultures and social systems and claims to represent the only valid understanding. Particularly in collective and shame orientated cultures, the recommendation of this leadership theory has a rather negative effect.

- The American leadership theory springs from the unrestricted mandate of the leader (Clinton, 1992:13 ff.). In the last analysis it is always about the leader. The theory is therefore perceived as a potentially totalitarian system, demoralising and endangering society. Democratic structures are being claimed, yet, rigid hierarchies are potentially introduced.

- The American leadership theory is being perceived as mercantile and market orientated. Predominantly it is always geared to-

9 Cf. Medinski's (2008a; 2008b) remarkable two-volume work on the myths about Russia. His work seeks to abolish prejudices which the West has against the Russians and their inability to dismantle democracy and to, at the same time, claim a new self-awareness in the country for the right to an autonomous development. 
wards profit maximisation and other values are far too quickly pushed into the background.

It would be wrong to speak about the American leadership theory. Covey does not represent the entire United States of America. Nowhere in his book is Tarassenko giving generalisations. He does not write against all American leadership theory, but rather questions Covey's view of leadership. Yet in the manner in which he does this, he shows clearly that a new wind is blowing in the scientific and practical debate regarding the question of leadership competence. In any event, the Russians are no longer willing to accept the western dominance regarding this question. They ask questions which are insightful and well formulated. It appears that the future of leadership in Russia will occur beyond western models; it will be postHarvard and post-Western. The time of the uprising in Russia against the totalitarian Soviet regime and its leadership theory is something of the past. Yesterday's young people, who were dazzled by the glory of western democracy and were prepared to cast all Russian cultural values to the wind, have now grown up. Young people today find it difficult to climb to positions of power in politics and society (Nemcov, 2007:4). A new hierarchy of leaders has established itself, which developed through dialogue with the West. It learned from the West, but is no longer prepared to repeat the mistakes of the West. The West would be well advised to listen to this voice and to seek a constructive dialogue.

\section{Outlook - perspective - prospect}

In summary, western leadership principles, with regard to economicsocial conditions, did not stand the test of time in Russia. Today, Tarassenko's criticism must be taken seriously in Russian society. Russia is not in need of a western, "universal" leadership theory, but rather a culturally adapted contextual theory of leadership, which takes both universal principles and cultural and context-specific conditions seriously. Only in this manner can the desired transformation of the country take place.

Theologically, Covey's "higher principles" make some sense. Submitting personal interests to the authority of higher principles based on God, will free the individual for greater effectiveness, provided those higher principles are theologically valid. The question is, however, how a given society can be forced to accept godly principles. How do you design an organisation guided by such principles? And is this after all realistic without damaging the principles themselves, for they are, theologically speaking, based on personal and not or- 
ganisational decisions. Such fundamental issues require mission and evangelism, not just organisational restructuring. Forced submission always ends with an ideology of dictatorship, even when the principles introduced are theologically correct. A Christian dictator is in no way better than an atheist. Tarassenko fears the return to the old age of ideology which totally dominated and squeezed the individual during the time of the Soviet regime. With the loss of personal individuality, the effectiveness of the individual in all organisational settings suffered immensely. Higher principles designed to minimise individual freedom were not at all helpful.

The new Russian leadership elite seems to be aware of such possible false alternatives. The questions they ask are valid and Tarassenko's critique provides the best illustration for this. Questions are, however, not yet a theory. Tarassenko does not provide his own concept of leadership. It will be fascinating to see how he and other Russian leadership experts pursue the important task of developing theories of organisational leadership that go beyond Covey's approach.

\section{List of references}

ADISES, I. 2007. Ideal'nii rukovoditel'- pochemu im nel'sia stat'i cto is etogo sleduet. Moskva: Alpina-Business Books.

CHAVANCE, B. 1994. The transformation of communist systems: economic reform since the 1950s. Oxford: Westview.

CLINTON, R.J. 1992. Der Werdegang eines Leiters: Lektionen und Stufen in der Entwicklung zur Leiterschaft. Greng-Murten: Verlag für Kulturbezogenen Gemeindebau.

COVEY, S.R. s.a. Leadership training. http://www. franklincovey.com/tc/

COVEY, S.R. 2000. Die sieben Wege zur Effektivität: ein Conzept zur Meisterung ihres beruflichen und privaten Lebens. München: HeyneCampus.

COVEY, S.R. 2006. Der 8. Weg: mit Effektivität zur wahren Größe. Offenbach: Gabal.

GORBATSCHOW, M.I. 1987. Perestroika: die zweite russische Revolution eine Politik für Europa: Buch zur Umgestaltung der sozialistischen Staaten. München: Droemer Knaur.

IBM Institute for Business Value. 2009. http://www-935.ibm.com/services/ us/gbs/bus/html/bcs_whatwethink.html Date of access: 1 Jan. 2009.

KAGARLITSKY, B. 1995. Restoration in Russia: why capitalism failed. London: Verso.

KAMPFNER, J. 1994. Inside of Yeltsin's Russia. London: Cassell.

KOVI, S. 2007. 8 navik: ot effektivnosti k velichiu. Moskva: Alpina Business Books.

KOVI, S. 2008. Sem' navikov visokokvalificirovannich liudei: Moshnie instrumenti razvitia lichnosti. Moskva: Alpina Business Books. 
LESSNER, E. \& STORK, J. 2006. Soobschestva praktikov i resultati dejatel'nosti organisacii. Hrsg. von E. Lessner \& P. Lorens. Moskva. Kakprevratit'znania $v$ stoimost': Reschenia IBM Institute for Business Value.

MEDINSKI, V. 2008a. O russkom rabstve, griasi I "tiurme narodov": Mifi o Rossii. Moskva: OLMA.

MEDINSKI, V. 2008b. O russkom píanstve, leni I zestokosti: Mifi O Rossii. Moskva: OLMA.

NEMCOV, B. 2007. Ispoved buntaria. Moskva: Partisan.

REIMER, J. 2009. Die Welt umarmen: Theologie des gesellschaftsrelevanten Gemeindebaus.

SASLAVSKAYA, T.I. \& ARATUNYAN, L.A. 1994. Kuda idjot Rossia? Alternativyobsestvennogo razvitija. Moskva: Interpraks.

STEELE, J. 1994. Eternal Russia: Yeltsin, Gorbachev and the mirage of democracy. London: Faber \& Faber.

TARASSENKO, V. 2006. Kniga bizness-peremen: 64 strategemy. Moskva: Genesis.

TARASSENKO, V. 2008. Ostorozno Stiven Kovi. Moskva: Dobraia Kniga.

\section{Key concepts:}

culturally relevant leadership

leadership

Perestroika

Russia

\section{Kernbegrippe:}

kulturele relevante leierskap

leierskap

Perestroika

Rusland 
